\title{
The Effects of NGOs on Socio-Economic Empowerment of Women: Empirical Evidence from Some NGOs Operating in Ethiopia
}

\author{
Diriba Ayele Gebisa Sori Tefera \\ Ambo University, Department of Management
}

\begin{abstract}
Women have been the most disadvantaged and discriminated sections of society all over the world, particularly in developing countries. This study aimed to investigate the effects of NGOs on socio-economic empowerment of women by conceptualizing and developing five basic dimensions of women empowerment including income, saving, decision-making ability, expenditure level, and assets ownership rights of women based on empirical evidence from some NGOs operating in Ethiopia. To test the hypotheses in this paper the researcher targeted three NGOs operating in the study area for a long period of time. For analysis purposes data were collected from 80 respondents selected proportionally by stratified random sampling technique. Data collected classified, edited, and analyzed using SPSS V20. The result of the five hypotheses tested indicated the existence of a positive and significant statistical difference at $5 \%$ of significant level between prior and post involvement of women in the various intervention approaches mainly micro credit and training offered on different issues of empowerment by the NGOs to empower the women' socio-economic perspectives.
\end{abstract}

Keywords: Poverty, Empowerment, and NGOs

DOI: $10.7176 / \mathrm{JESD} / 11-1-04$

Publication date: January $31^{\text {st }} 2020$

\section{Introduction}

According to Taylor and Pereznieto (2014) women's economic empowerment is the method of realizing women's equal accessibility and control over economic resources. Achievement of women empowerment is now a global policy priority for its potential effects on the sustainable Development Goals of the United Nation (UN) that targets poverty reduction, well-being and human development. The achievement of these goals besides the government partially realized through Non-Governmental Organization (NGOs).

The emergence of NGOs have centered on their ability to offer a development alternative, making a set of claims about the more effective approaches necessary for addressing poverty and challenging unequal relationships (Bebbington et al, 2008; Lewis and Kanji, 2009) and NGOs can fill the gaps caused by inefficient state provision of services of rehabilitation, namely, economic, social, educational and medical (Lang, 1999).

International and indigenous non-government controlled welfare and community organizations have existed for long time all over the world. However, in the last three decades, Non-Governmental Organizations (NGOs) have expanded and grown enormously in developing country for the humanity and socio-economic problem of the society. Emerging from long-term traditions of charity and self-help group, NGOs vary widely in origin and levels of formality (Lewis and Kanji 2009). The NGOs found in the form of religious groups, private foundations, charities, research organizations, and federations of dedicated physicians, civil society organizations, and citizen associations.

It is argued that where government lack public services, NGOs play a significant role in the direct provision of social and economic services. Similarly, in developing countries, NGOs emerged and play the roles as service providers and significantly NGO worked on poverty alleviation and reducing income inequality. As Vakil (1997) explained the perceived failures of state led development approaches throughout the 1970s and 1980s powered interest in NGOs as a development alternative, offering innovative and people-centered approaches to service delivery, advocacy and empowerment.

Most of international and domestic NGOs working in Ethiopia are religious based and had been working in relief, rehabilitation and development works and they are active in their operations. Most of them are working with the marginalized people at the grass root level. The emergency of large number of new NGOs and expansion of NGOs in Ethiopia related to the devastating drought in the 1974/75, and again in the 1984/85. From that time onwards NGOs highly expanded in Ethiopia and offered variety of services and designed and implemented various development projects that support socio-economic development of the country.

The purpose of this study is to analyze the effects of NGOs on socio-economic empowerment of women and developed five hypotheses, stating there is statistically significant difference in the income, saving; decision making, expenditure level of women and assets ownership rights of the participated women prior and post involvement in NGOs intervention program. The investigation of this research focused on the effect of NGOs on social and economic empowerment of women exposed to the NGOs empowerment approaches. This paper is 
organized as follows: section 2 provides a theoretical and empirical review of the literature. Section 3 formulates the theoretical framework of the study. Section 4 presents the results, and finally section 5 present the conclusion.

\section{Result and Discussions}

The survey instrument done on respondents profile with respect to their age, educational level, and marital status; respecting the age distributions of the women respondents about $58.75 \%, 32.50 \%, 2.5 \%$ and $5 \%$ are between age 41-50, 31-40, 20-30 and above 51 respectively. Similarly, respecting the marital status, majority of the respondents were married; and on average the respondents included in this survey had completed elementary school and only small fraction of them never attended school at all. Generally, no significant differences observed among the women involved in the NGOs under investigation regarding their demographic status of age, marital status and education.

The designed survey questionnaire under different categories of Likert scale model to measure the effects of the NGOs on the social and economic status of the poor women under the NGOs intervention program analyzed in the following section.

\section{NGOs' intervention programs and women empowerment}

It is well known that the first goal of the millennium development programs (MDGs) is eradication of extreme poverty and hunger. Poverty is one of the most important global problems, and the fight against poverty is becoming a vital of our age. The eradication of poverty highly concern women since large percentages of women greatly live in absolute poverty and due to the seriousness of the problem and increasing trends of people under serious poverty the United Nations have declared 2008-2017 as the Second Decade for the eradication of Poverty (Sach, 2005).

Improving the status of women is an integral part of the work of eradicating poverty and building civil society. Poverty can only be eradicated if women half of the world's populations are educated and strong enough to generate income for themselves and their families.

The summarized response of the women on intervention mechanisms used by the three NGOs under investigation to alleviate poverty are expansion and provision of education and education facility, establishment and offering of medical services at low cost and free treatment and services without costs for some special issues, construction of public projects like water supply and sanitations services, basic skills training for income generation activities and saving habits, awareness creation on environmental protection and wise usage of natural resources.

\section{Effects of NGOs intervention program on Income levels of women}

Women's poverty is directly related to the absence of economic opportunities and autonomy including credit, land ownership and inheritance, and participation in the decision-making process. Improving the status of women is an integral part of the work of eradicating poverty. Poverty can only be eradicated if women half of the world's populations are educated and strong enough to generate income for themselves and their families. Around the world, many programs target women in an attempt to reduce poverty: a goal which empowers women in many other ways. Microcredit programs are a key example. When women receive small loans to start their own small businesses, they gain experience, confidence, practical skills and economic independence.

All of these skills and experiences go beyond simple economic improvement and lead women toward taking active roles in their lives and the lives of their communities. The income generating activities enable women to have access to income, and enhanced decision-making on health, education, consumption, etc. Women also interact with outside markets and the community, and this process gradually enables them to play an active role in social, political and economic issues affecting themself, household and the community (Mayoux 1998). White (1991) on Bangladesh women borrowers as well as by Mbilinyi and Omari (1993) in Tanzania, how credit facilities had improved the income of low income women.

Table $\mathrm{C}$ given in the appendix part of this research shows the descriptive statistics on the differences of income levels of the poor participants' women before and after involvement in income generating activities designed and sponsored by NGOs to empower and alleviate poverty. As it is shown on the table, the income levels before joining the NGOs program $23.88 \%$ of the participants had no anything of income; however after involvement in the NGOs program all of them had started to earn some amount of income; whereas prior involvement majority, $62.68 \%$, of them were under very low income category, however after involvement in the NGOs $46.27 \%$ of the women participated were grown to high income earning category.

Generally, post involvement in the NGOs income generating program a radical change observed in the last two income ranges of high and very high, where formerly none of them had earned that ranges of income latter on $19(28.36 \%)$ and $6(8.95 \%)$ of them had lies between high and very high income ranges. From the above analyzed data there was a significant change on income levels of the participants between post and prior involvement in NGOs. This finding confirm, the result of Asmelash (2003) from the study conducted in Tigray region that the 
credit provided to the poor has brought a positive impact on the life of the clients as compared to those who do not get access to the credit services.

\section{NGOs intervention program on saving capacity of women}

Getting income and consuming alone has no value unless that part of income is saved to serve future growth. From the discussion made above under the NGOs intervention mechanisms' programs for women empowerment, one is development of the saving habits of the poor women from their small incomes. The descriptive statistics result of the effects of the NGOs on the saving levels of the poor grass roots women show that earlier to the training and awareness creation program and participation in income generation program by the NGOs, $38 \%$ had saved nothing and $43 \%$ of them were within category of very low saving level, whereas post involvement in NGOs empowerment intervention program $31 \%$ of them were within medium saving category and $55 \%$ were within high saving level category. Prior none of them were within very high saving category while post involvements $13 \%$ of them were within very high saving category.

From the analysis, $82.08 \%$ of the respondents had saved below very low saving category, i.e Birr 260 annually prior involvement, but post involvement none of the respondents were below this saving levels, while $13.4 \%$ of the poor participants women had saved between low saving category (Birr 261-520) per year prior involvement but late involvement the number of participants who had saved between this range increased to $31.34 \%$.

Besides the frequency distribution, the mean distribution of the saving levels prior in was very low but after intervention significantly increased. Similarly, the standard deviation of the saving levels among the participants after taking part in the program was slightly decreased and shown marginal improvement in income inequality.

To sum up the significant difference in the saving levels was the result of accessibility to affordable credit or finance and training services designed and given frequently to enhance the income levels and to foster saving habit of the participants to improve their wellbeing and security.

\section{NGOs intervention program on decision making ability of women}

Poverty is perceived and experienced differently by men, women and social classes. In the society the controller of resources has more power to influence socio-politics and poverty alleviation. Intra-household inequalities in making decision affect women's power in alleviating poverty because they cannot make decision in allocation or distribution of resources at the household level or at higher entrepreneurial levels.

Besides the economic marginalization, women are marginalized in decision making in the family and society level. Regarding the action of the NGOs in enabling improving women decision making ability, the result show that prior intervention program only $10.45 \%$ of the participants had participated in personal and family decision making, but late involvement income generating program majority, $83.58 \%$, of them were started to be involved in personal and family decision making.

Besides the frequency distribution there was also difference in coefficient of variations $(\mathrm{CV})$ in pre and post decision making ability. The analyzed data revealed that in a situation where formerly women have been marginalized in household decision-making process, intervention by the NGOs improved their role in decisionmaking process.

\section{NGOs intervention program on assets ownership rights of women}

In measuring poverty or wealth of women, the level of their access to and control over resources must be considered. This is because from a gender perspective, power over resources is a key concept on poverty (Mbughuni, 1994). The controller of resources has more power in poverty alleviation; poverty is also linked to lack of access by the poor households to the assets necessary for a higher standard of income or welfare (World Bank, 2000).

The descriptive statistics revealed a slight increase in the enjoyment levels of women to assets ownership right post involvement in poverty alleviation and women empowerment program of the NGOs. Prior intervention program only $16.42 \%$ of the women had full ownership rights on her family's asset but after participation in intervention program the number of women enjoyed to assets ownership right increased by $26.86 \%$ and become $43.28 \%$.

On the other hand, the statistics show a relative decrease in the standard deviation and coefficient of variations The findings indicate that the NGOs actions significantly enabled women to enjoy assets ownership rights; however, all participants had not fully enjoyed assets ownership rights even after they owned their own income and assets, however it is on promising trend.

\section{Hypothesis Testing}

The summary of hypothesis testing is outlined below.

Hypothesis 1: There is statistically significant difference between income levels of the participants' women between the prior involvement and post involvement of NGOs.

The analysis shows the existence of significant difference, where the calculated $\mathrm{x}^{2}$ is statistics is much greater 
than the critical value, $124.05>11.07$, at $\alpha=0.05$. That is the result show that there is statistically significant difference in the income levels of participants' women prior and post involvement in NGOs.

In other words, the statistic is large enough since some of the cells have large discrepancies between the observed and expected frequencies. Thus, the null hypothesis can be rejected since the $\mathrm{P}$ value statistic is too small relative to the calculated $X^{2}$. This suggests that the there is a significant difference in income levels of participated women prior and post involvement in NGOs. Thus, women empowerment programs by the NGOs had significantly affecting income of the women involved in the NGOs intervention program.

Hypothesis 2: There is statistically significant difference between saving levels of the participants prior and post involvement in NGOs. The result of the second hypothesis (Ho) show the non-existence of statistically significant difference in the prior and post saving levels of the women. This hypothesis is supported by the analysis that shows the existence of significant difference, where the calculated $\mathrm{x} 2$ is statistics is much greater than the critical value, $76.51>9.488$, at $\alpha=0.05$, which suggests the existence of statistically significant difference in the income levels of participants' women prior and post involvement in NGOs.

Hypothesis 3: There is statistically significant difference in the enjoyment of asset ownership rights in the period prior and post involvement of NGOs. This hypothesis is supported by calculated value of $\mathrm{X}^{2}$ is $39.96456>$ $7.81(\mathrm{df}=3$ at 0.05$)$ of theoretical value; which suggests that involvement in NGOs empowerment intervention program enables women to enjoy assets ownership rights from the assets they accumulated from the intervention program.

Hypothesis 4: There is statistically significant difference in expenditure level of women on family/personal matters before and after involvement in NGOs. The hypothesis analysis shows the existence of significant difference, where the calculated $\mathbf{x}^{2}$ value is much greater than the theoretical value, $(75.59>5.99)$, at $\alpha=0.05$. That is the result show that there is statistically significant difference in expenditure level of women before and after involvement in NGOs.

Hypothesis 5: There is significant difference in women decision making at the family level and in the society between prior and post involvement of NGOs. There is statistically significant difference in decision making level of women on family/personal matters before and after involvement in NGOs. The hypothesis analysis shows the existence of significant difference, where the calculated $\mathbf{x}^{2}$ value is much greater than the theoretical value, (54.387> 5.991), at $\mathrm{df}=3, \alpha=0.05$. That is the result show that there is statistically significant difference in decision making level of women before and after involvement in NGOs

\section{Conclusions}

The objective of this study is to investigate the effects of NGOs on socio-economic empowerment of women. Women's socio-economic empowerment is fundamental for poverty eradication, gender equality, better families' well-being, and comprehensive economic growth. Overcoming these problems requires bold and compressive strategies. This study focused on five key factors that indicate the effects of NGOs on women empowerment levels; and the intervention approaches by the NGOs. The major factors considered were income, saving, decision making ability, expenditure levels, and assets ownership rights of the poor women as a result of the intervention program by the NGOs.

The results of the tested hypothesis show the existence of significant effects of the NGOs intervention program on the tested variables. Similarly, for the empowerment of the poor women at grass root levels the NGOs under considerations used approaches of lending of money at low interest, awareness creation training on different aspects, lending money free interest rate, supplying foods and health services in special cases, and transfer payments for elderly and disabled poor women.

\section{References}

1. Belshaw, Deryke Coyle, Erin (2001): Poverty Reduction in Ethiopia and the Role of NGOs: Qualitative Studies of Selected Projects, Report of a Consultancy Assignment, Addis Ababa, Ethiopia. Available from: http://www.odi.org.uk/resources/download/1486.pdf. Accessed in September 2012.

2. Challenges and Weaknesses of Non-Governmental Organizations (NGOs) in Africa: The Case of Indigenous NGOs in Ethiopia Sisay Gebre-Egziabher Christian Aid Ethiopia, Addis Ababa, Ethiopia ISTR 20100461 pdf. Accessed in September 2012.

3. Saifuddin, Ahmed (2006): NGO Perception of Poverty in Bangladesh: Do their programmes match the reality? University of Bergen, Department of Administration and Organization Theory, Norway. Available from: https://bora.uib.no/bitstream/1956/1473/1/Masteroppgave ahmed.pdf Accessed October 2012.

4. Suharko (2007): The Roles of NGOs in Rural Poverty Reduction: The Case of Indonesia and India, Discussion Paper No. 160, GSID - Nagoya Japan. Available from: http://www.gsid.nagou.ac.jp/bpub/research/public/ paper/article/1.pdf Accessed November 200.

5. Reflections from the Experience of the Humanitarian Reform Officer NGOs and Humanitarian Reform Project Ethiopia, By Dan Tyler: NGOs and Humanitarian Reform Officer in Ethiopia, Ethiopia lesson pdf. 
Accessed in October 2012.

6. Ethiopia NGO Law Monitor, Research Center - ICNL Ethiopia pdf. Accessed in December 2012.

7. Harry N. Boone, Jr. a Deborah A. Boonend, 2012, Analyzing Likert Data, Volume 50 Number 2 Article Number 2TOT2, West Virginia University, Morgantown, available at http://www.joe.org/joe/ 2012april/tt2p.shtml [8/20/2012 9:07:48 AM] Accessed in November 2012

8. Martin N Marshall, 1996, Sampling for qualitative research, Oxford University Press Vol. 13, No. 6 Printed in Great Britain. Accessed in October 2012

9. Dane Bertram, 2006, Likert Scales, from http://www.performancezoom.com /performances zoom fishers/likert.gif. Accessed in September 2012

10. The role of microfinance in empowering women in Addis Ababa a thesis submitted to the institute of gender studies of Addis Ababa University in partial fulfillment of the requirements for the degree of Master of Arts in gender studies by MeronHaileselassie July, 2007. 13136871051060 pdf. Accessed in November 2012

11. The role of NGOs and civil society in development and poverty reduction Nicola Bank with David Hulme, bwpiwp 17112 June 2012. Accessed in December 2012.

12. Gem mill, Barbara, Maria Ivanovo, andYoke LingChee. 2002. "Designing a New Architecture for Global Environmental Governance. BWPI Working Paper 171 Available from bamidele@hyperia.comhttp://www. Balogun bam idele.com/pdf. Accessed in November 2012.

13. "World Summit for Sustainable Development Briefing Papers , International Institute for Environment and Development (IIED),London. Available

from http://www.poptel.org.uk/iied/test/searching/ring_pdf/wssd_21_international_environmental_governance.pdf Accessed in November 2012

14. Simmons, P. J. 1998."Learning to Live with NGOs.”Foreign Policy, Fall1998: 82-96. Available from http://www.globalpolicy.org/ngos/issues/simmons.htm Accessed in November 2012.Accessed in October 2012

15. Weiss, Thomas G. 1999."International NGOs, Global Governance and Social Policy in the UN System." Globalism and Social Policy Programme, Helsinki,Finland.Availablefromhttp:/www.stakes.fi/gaspp/occasional\%20papers/gaspp3-1999.pdfAccesed in December 2012.

16. UN. 1994. Agenda 21: The United Nations Programme of Action forSustainable Development. New York: United Nations. Available from http://www. un.org/ esa/sustdev/agenda21 text.htm

17. International NGO Journal Vol. 4 (10) pp. 446-455, October 2009 Available online at http:// www.academicjournals.org/ingoj ISSN 1993-8225 (C) 2009. Accessed in October 2012

18. Academic Journals Poverty alleviation and service delivery - developing a conceptual framework for South Africa's service delivery system. Accessed in November 2012

19. Mubangizi, Special paper 07.21 pdf Mercer, Discussion Paper No.160. The Roles of NGOs in Rural Poverty Reduction: The Case of Indonesia and India Suharko October 2007, GSID Nagoya, pdf. Accessed in November 2012

20. Poverty reduction in Ethiopia and the role of NGOs: qualitative studies of selected projects, DerykeBelshaw and Erin Coyle Report of a Consultancy Assignment carried out by the Overseas Development Institute, London on behalf of the Christian Relief and Development Association, Addis Ababa, Ethiopi 2207 pdf

21. The Role of Local NGOs in Promoting Participation in CBR Basil Kandyomunda, ServiousDube, Maria Kangere, MekdesGebretensay. cbr11pdf. Accessed November 2012.

22. Empowering Women in Rural Bangladesh: Impact of Bangladesh Rural Advancement Committee's (BRAC's) ProgrammeDilrubaBanuFehminFarashuddinAltafHossainShahnujAkterdilirubapdf. Accessed in December 2012.

23. Federal democratic republic of Ethiopia disaster prevention and preparedness commission donor $\mathrm{r}$ elations \&resource mobilization strategy donors relation support pdf. Accessed in November 2012.

24. Micro-finance and women empowerment: role of non-government organizations ManjulaBolthajjiraChengappaSt.Agnes College, Mangalore/Karnataka, India, Mangalore University, Mangalore/Karnataka, In ISTR 20100212 PDF Journal of Social Development in Africa(1999),14,1,19-30. Accessed in November 2012.

25. One NGOs Contribution to Women's Economic Empowerment and Social Development in Zimbabwe MARIAJULIA* Jsda 014001300 pdf. Accessed in November 2012

26. Journal of International Development J. Int. Dev. 18, 665-675 (2006) Published online in Wiley InterScience (www.interscience.wiley.com) DOI: 10.1002/jid.1306 Lewis opukupdf

27. Micro-finance, poverty alleviation and empowerment of women: a study of two NGOS from Andhra Pradesh and RarnatakaRajasekha institute for social and economic change Bangalore 2004. Accessed in October 2012.

28. Acharya, Meena, 2007. Gender Equality and Empowerment of Women, UNFPA.

Aithal, Vathsala, n.d. Empowerment and global action of women.Availablat: http://www.s kk. 
uit.no/WW99/papers/Aithal Vathsala.pdf. Accessed in November 2012.

29. NGOs working to reduce poverty Written by By The Independent Team Tuesday, 01 September 2009 18:30 1581 NGOs working to reduce poverty

30. Court J, Maxwell S. 2005. Policy entrepreneurship for poverty reduction: bridging research and policy in international development. Journal of International Development 17: 713-725. Accessed in December 2012

31. Igoe J, Kelsall T. (eds). 2005. Between a Rock and a Hard Place: African NGOs, Donors and the State. Academic Press: Carolina, Durham, NC. Accessed in November 2012

32. Helvetas Nepal, n.d. Empowering women, Learning and sharing series No.2. Available at http://www. helvetasnepal.org.np/ Publication /Learning 2.pdf. Accessed in November 2012

33. TerefeAsfaw (1998) The Contribution of the Voluntary Sector and the Role of NGOs and Church-based Agencies in the Educat ion Sector. Pape $r$ presented at a CRDA/Ministry of Education Workshop on 'The Role of NGOs in Education'. Addis Ababa. Accessedin December 2012

34. Uvin, Peter., Jain, Pankaj S., \& Brown, L.David. 2000. "Think Large and Act Small: Toward a New Paradigm for NGO Scaling Up”. World Development, Vol 28, No.8, pp1409-1419. Accessed in December 201 